OPEN ACCESS

Edited by:

Mukesh Kumar Kanwar,

Zhejiang University, China

Reviewed by:

Matthew John Milner,

National Institute of Agricultural Botany (NIAB), United Kingdom

Harminder Pal Singh,

Panjab University, India

*Correspondence:

Syed Asad Hussain Bukhari bukhariasad@yahoo.com

Shafaqat Ali

shafaqataligill@yahoo.com

Specialty section:

This article was submitted to

Plant Nutrition,

a section of the journal

Frontiers in Plant Science

Received: 30 March 2020

Accepted: 17 September 2020

Published: 23 October 2020

Citation:

Ali E, Hassan Z, Irfan M, Hussain S, Rehman H-u, Shah JM,

Shahzad AN, Ali M, Alkahtani S, Abdel-Daim MM, Bukhari SAH and Ali S (2020) Indigenous Tocopherol Improves Tolerance of Oilseed Rape

to Cadmium Stress.

Front. Plant Sci. 11:547133.

doi: 10.3389/fp/s.2020.547133

\section{Indigenous Tocopherol Improves Tolerance of Oilseed Rape to Cadmium Stress}

\author{
Essa Ali', Zeshan Hassan', Muhammad Irfan ${ }^{3}$, Shabir Hussain ${ }^{3}$, Haseeb-ur-Rehman ${ }^{3}$, \\ Jawad Munawar Shah², Ahmad Naeem Shahzad ${ }^{3}$, Murtaza Ali4, Saad Alkahtanis, \\ Mohamed M. Abdel-Daim ${ }^{5,6}$, Syed Asad Hussain Bukhari ${ }^{*}$ and Shafaqat Ali7,8*
}

\footnotetext{
${ }^{1}$ Department of Food Science and Technology, Zhejiang University of Technology, Hangzhou, China, ${ }^{2}$ College of Agriculture, Bahauddin Zakariya University, Layyah, Pakistan, ${ }^{3}$ Department of Agronomy, Bahauddin Zakariya University, Multan, Pakistan, ${ }^{4}$ Department of Basic Sciences and Humanities, University of Engineering and Technology, Mardan, Pakistan, ${ }^{5}$ Department of Zoology, College of Science, King Saud University, Riyadh, Saudi Arabia, ${ }^{6}$ Department of Pharmacology and Toxicology, Faculty of Veterinary Medicine, Suez Canal University, Ismailia, Egypt, ${ }^{7}$ Department of Environmental Sciences and Engineering, Government College University, Faisalabad, Pakistan, ${ }^{8}$ Department of Biological Science and Technology, China Medical University, Taichung, Taiwan
}

Two oilseed rape genotypes (Jiu-Er-13XI and Zheyou-50), differing in seed oil content, were subjected to cadmium (Cd) stress in hydroponic experiment. Genotypic differences were observed in terms of tolerance to Cd exposure. Cd treatment negatively affected both genotypes, but the effects were more devastating in Jiu-Er-13XI (low seed oil content) than in Zheyou-50 (high seed oil content). Jiu-Er-13XI accumulated more reactive oxygen species (ROS), which destroyed chloroplast structure and decreased photosynthetic pigments, than Zheyou-50. Total fatty acids, especially 18:2 and 18:3, severely decreased as suggested by increase in MDA content. Roots and shoots of JiuEr-13XI plants accumulated more Cd content, while less amount of tocopherol (Toc) was observed under Cd stress, than Zheyou-50. Conversely, Zheyou-50 was less affected by $\mathrm{Cd}$ stress than its counterpart. It accumulated comparatively less amount of $\mathrm{Cd}$ in roots and shoots, along with reduced accumulation of malondialdehyde (MDA) and ROS under Cd stress, than Jiu-Er-13XI. Further, the level of Toc, especially $\alpha$-Tocopherol, was much higher in Zheyou-50 than in Jiu-Er-13XI, which was also supported by high expression of Toc biosynthesis genes in Zheyou-50 during early hours. Toc not only restricted the absorption of $\mathrm{Cd}$ by roots and its translocation to shoot but also scavenged the ROS generated during oxidative stresses. The low level of MDA shows that polyunsaturated fatty acids in chloroplast membranes remained intact. In the present study the tolerance of Zheyou-50 to Cd stress, over Jiu-Er-13XI, is attributed to the activities of Toc. This study shows that plants with high seed oil content are tolerant to $\mathrm{Cd}$ stress due to high production of Toc.

Keywords: cadmium stress, oilseed rape, pigments, ultrastructure, tocopherols 


\section{INTRODUCTION}

Heavy metals are major environmental pollutants due to their detrimental effects on life. Severe concerns, related to ecology, evolution, nutrition, and environment, are associated with heavy metals (Hawkes, 1997). Due to exorbitantly increasing industrialization and urbanization, heavy metals are constantly penetrating the environment as industrial effluents and household wastes, posing a potential threat to the ecosystem. Heavy metals enter the food chain through plants grown on polluted soil or irrigated with contaminated water (Bukhari et al., 2016). Cadmium (Cd) is one of such hazardous metals piercing the environment by anthropogenic, as well as natural means (Lima et al., 2006). Cadmium becomes a part of the soil-plant environment as plants absorb water and nutrients from the soil. Cadmium can affect plants in many ways, especially by damaging their photosynthetic apparatus (Ali et al., 2015), reducing gas exchange ability (Jia et al., 2011), causing nutrient imbalance (Feng et al., 2013), subcellular changes like chloroplast, mitochondrial, and nuclear membrane disintegration (Liu et al., 1995; Wang et al., 2011; Ali et al., 2018), and destroying antioxidant defense systems (Ahmad et al., 2011). Moreover, exposure of plants to Cd stress inhibits cell growth (Di Toppi and Gabbrielli, 1999) and alters root morphology (Jia et al., 2011). In short, contamination of soil and water bodies with $\mathrm{Cd}$ and its subsequent absorption by plants are serious concerns threatening the agricultural production and human health globally (Wu et al., 2005). Cd-induced damage to plants is an outcome of overgeneration of reactive oxygen species (ROS). Cadmium cannot directly generate free radicals via Fenton and/or Haber Weiss reactions in biological systems. However, the accumulation of ROS in Cd-treated plants has been reported in literature (Pathak and Khandelwal, 2006; Zhou et al., 2009). Actually, Cd produces ROS indirectly by increasing the concentration of free Fe by replacing it in different proteins, compromising the integrity of the membranes by lipid peroxidation, which can be demonstrated by the increase in malondialdehyde (MDA) content (Scholz et al., 1990; Dorta et al., 2003). Plants combat Cd stress by virtue of certain enzymatic and non-enzymatic systems. In plants, tocopherols are considered as an important component of non-enzymatic protection against stresses.

Oilseed rape (Brassica napus L.), an important crop of temperate regions, provides edible oil, animal feed, and biodiesel. Its dry seed contains about 40-50\% oil content (Hüsken et al., 2005). Besides, oilseed rape contains lipid soluble tocopherols, also called vitamin E, which is a wellknown antioxidant against reactive oxygen species (ROS), and an essential nutrient for human beings and animals. Tocopherols, the constituents of compounds having vitamin $\mathrm{E}$, are synthesized by photosynthetic organisms only (MèneSaffrané and DellaPenna, 2010). Tocopherols are lipid-soluble molecules with four structural derivatives [alpha $(\alpha)$, beta $(\beta)$, gamma $(\gamma)$, and delta $(\delta)]$ having diverse biological functions. Tocopherols serve as antioxidants by annihilating singlet oxygen and neutralizing the harmful radicals to inhibit lipid peroxidation of membranes (Sattler et al., 2004a; Krieger-Liszkay, 2005).
In vitro, each molecule of $\alpha-, \beta-, \gamma$-, and $\delta$-tocopherol can protect up to $220,120,100$, and 30 molecules of polyunsaturated fatty acids (PUFAs), respectively (Fukuzawa et al., 1982). Plant tissues vary massively in their tocopherol content and composition (Grusak et al., 1999). Photosynthetic tissues contain 10 to $50 \mathrm{mg}$ tocopherol/g fresh weight (FW), with $\alpha$ - tocopherol the dominant one, while seeds vary from 300 to $2,000 \mathrm{mg}$ tocopherol/g oil, where $\gamma$-tocopherol is a main constituent (Grusak, 1999). This variation in tocopherol content and composition is attributed to a variety of environmental and genetic factors. Photosynthetic tissues, especially leaves, are highly responsive to environmental variations. However, tolerant plants generally exhibit enhanced tocopherol levels, while susceptible ones display net reduction in tocopherol content under stress. Alpha tocopherol shows a remarkable increase under water deficit conditions (GarciaPlazaola and Becerril, 2000; Munne-Bosch and Alegre, 2001). Further, tocopherol content of plants increase in response to various abiotic stresses like salinity, light, cold, and heavy metals, which may offer a supplementary line of defense against oxidative deterioration (Havaux et al., 2000; Munne-Bosch and Alegre, 2002b; Tang et al., 2016; Gramegna et al., 2019; Nowicka et al., 2020). Based on increasing tocopherol content in response to abiotic stresses (Kim et al., 2019), it is believed that protection of PUFAs from oxidative damage is the main function of tocopherols (Havaux et al., 2000; Collakova and DellaPenna, 2003; Abbasi et al., 2007; Collin et al., 2008). The current study was designed to probe the response of two Brassica napus genotypes, differing in oil content, to Cd stress in terms of fatty acids and tocopherol levels.

\section{MATERIALS AND METHODS}

\section{Plant Materials and Treatments}

A hydroponic trial was carried out under natural light conditions in a net house of the Zijingang campus, Zhejiang University, Hangzhou, China. Two rapeseed genotypes, Zheyou-50 (high seed oil content) and Jiu-Er-13XI (low seed oil content), were used in the experiment ( $\mathrm{Du}$ et al., 2015). The seeds were sown in trays containing $50 \%$ compost, $25 \%$ vermiculite, and $25 \%$ sand in the growth chamber. After 1 month, seedlings were transferred to the wire house to adapt to the outside environment. Morphologically similar and healthy seedlings were shifted to 5 -L buckets having $4.5 \mathrm{~L}$ of nutrient solution $\left(\mathrm{mg} \mathrm{L}^{-1}\right):\left(\mathrm{NH}_{4}\right)_{2} \mathrm{SO}_{4}, 48.2 ; \mathrm{MgSO}_{4}, 65.9 ; \mathrm{K}_{2} \mathrm{SO}_{4}, 15.9 ; \mathrm{KNO}_{3}$, 18.5; $\mathrm{Ca}\left(\mathrm{NO}_{3}\right)_{2}, 59.9 ; \mathrm{KH}_{2} \mathrm{PO}_{4}, 24.8 ;$ Fe-citrate, $7 ; \mathrm{MnCl}_{2}-$ $4 \mathrm{H}_{2} \mathrm{O}, 0.9 ; \mathrm{ZnSO}_{4}-7 \mathrm{H}_{2} \mathrm{O}, 0.11 ; \mathrm{CuSO}_{4}-5 \mathrm{H}_{2} \mathrm{O}, 0.04 ; \mathrm{HBO}_{3}$, 2.9; $\mathrm{H}_{2} \mathrm{MoO}_{4}, 0.01$. The $\mathrm{pH}$ of the nutrient solution was maintained at $5.8 \pm 0.1$ using $\mathrm{HCl}$ or $\mathrm{NaOH}$. The containers were covered with plates having eight evenly spaced holes (one seedling per hole) and placed in a net house. One week after transplantation, $\mathrm{Cd}\left(\right.$ as $\left.\mathrm{CdCl}_{2} \cdot 2 \cdot 5 \mathrm{H}_{2} \mathrm{O}\right)$ was added to the corresponding containers to form two treatments: basal nutrient solution (control), and $100 \mu \mathrm{M} \mathrm{Cd}(\mathrm{Cd})$. The containers were continuously aerated using pumps, and the nutrient solution was renewed after every 5 days. The experimental treatments were adjusted in randomized complete block design (RCBD) with 
three replications. Samples for gene expression and quantification of ROS were collected at 12, 24, and $48 \mathrm{~h}$ after treatment (HAT). For other parameters, samples were harvested at 3, 6, and 9 days after treatment (DAT) and stored at $-80^{\circ} \mathrm{C}$ for subsequent analysis.

\section{Quantifying Leaf Photosynthetic Pigments}

Photosynthetic pigment contents ( $\mathrm{Chl} \mathrm{a,} \mathrm{Chl} \mathrm{b}$, and carotenoids) were determined according to the method described by Wang et al. (2009). Briefly, 10 fresh leaf disks (diameter, $1 \mathrm{~cm}$ ) were placed in a glass tube containing a mixture of ethanol, acetone, and distilled water $(4.5: 4.5: 1)$ and stored at $4^{\circ} \mathrm{C}$ for $48 \mathrm{~h}$ in the dark. The absorbance of the extract was noted at 645 and $663 \mathrm{~nm}$ on a spectrophotometer.

Formula for chlorophyll determination (mg/g FW):

$$
\begin{aligned}
& \text { Chl. }(\mathrm{a})=12.71 \times \text { OD663 }-2.59 \times \text { OD } 645 / 100 \\
& \text { Chl. }(b)=22.88 \times \text { OD645 }-4.67 \times \text { OD663/100 } \\
& \text { Total chlorophyll }=\text { Chl. }(a)+\text { Chl } .(b)
\end{aligned}
$$

\section{Determination of MDA Content}

Leaf tissues $(0.5 \mathrm{~g})$ were crushed and blended with $8 \mathrm{ml}$ of $50 \mathrm{mM}$ phosphate buffer (PBS, $\mathrm{pH} 7.8$ ) solution under icecold conditions. Homogenate was subjected to centrifugation at $12,000 \mathrm{rpm}$ and $4^{\circ} \mathrm{C}$ for $15 \mathrm{~min}$. The supernatant was collected to determine malondialdehyde (MDA) content as described by Hodges et al. (1999). The mixture of reaction solution (5\% TCA solution with $2.5 \mathrm{~g}$ TBA) and sample extract was heated at $95^{\circ} \mathrm{C}$ for $15 \mathrm{~min}$ in a water bath, followed by immediate cooling on ice. After centrifugation at 4,800 rpm for $10 \mathrm{~min}$, the supernatant was run on a spectrophotometer to record the absorbance at $532 \mathrm{~nm}\left(\right.$ E532 $\left.=1.55 \times 10^{-1} \mathrm{mM} \mathrm{cm}^{-1}\right)$. Non-specific turbidity was corrected by subtracting the value of absorbance taken at $600 \mathrm{~nm}$.

\section{Determination of $\mathbf{C d}$ Accumulation}

About $0.1 \mathrm{~g}$ of oven-dried (at $65-70^{\circ} \mathrm{C}$ for $72 \mathrm{~h}$ ) tissues of shoot and root were crushed for the determination of $\mathrm{Cd}$ concentration. Mineralization was performed by heating $5 \mathrm{ml}$ of $65 \% \mathrm{HNO}_{3}$ using a microwave digester (Microwave 3000; AntoonPaar). The volume of the digested samples was raised to $10 \mathrm{ml}$ by adding Milli-Q water. Specimens were run on inductively coupled plasma-optical emission spectrometer (ICPOES; Optima 8000DV; PerkinElmer) to quantify the Cd content.

\section{Leaf Tissue Reactive Oxygen Species Staining and Quantification}

Leaves harvested at 12,24 , and $48 \mathrm{~h}$ after treatment were processed for ROS quantification. $\mathrm{H}_{2} \mathrm{O}_{2}$ and $\mathrm{O}_{2}{ }^{-}$contents were quantified using the method suggested by Jiang and Zhang (2001) and Gong et al. (2008), respectively.

\section{Determination of Tocopherol Content}

Tocopherols were extracted and analyzed by the method suggested by Li et al. (2013) with minor changes. About
$100 \mathrm{mg}$ of fresh leaf discs were placed in a 2-ml skirted screw-cap microtube having $1.3 \mathrm{ml}$ of $\mathrm{n}$-hexane. Samples were macerated using bead mill homogenizer (Bead Ruptor-24, Omni, Kennesaw, GA, United States) at $8 \mathrm{~m} \mathrm{~s}^{-1}$ for $30 \mathrm{~s}$ and incubated for $15 \mathrm{~h}$ under dark conditions. The supernatant $(20 \mu \mathrm{l})$ was subjected to normal-phase high-performance liquid chromatography machine (model 600, Waters, Milford, MA, United States) fitted with a Zorbax Rx-SIL column $(4.6 \mathrm{~mm} \times 250 \mathrm{~mm} \times 5 \mu \mathrm{m}$; Agilent, Englewood, CO, United States) and a fluorescence detector ( $\lambda$ ex $=295 \mathrm{~nm}$; $\lambda$ em $=330 \mathrm{~nm})$. The mobile phase of hexane/tert-butyl methyl ether $(95: 5, \mathrm{v} / \mathrm{v})$ was transported at a constant rate of $1 \mathrm{ml}$ $\mathrm{min}^{-1}$. Isoforms of tocopherol were quantified using the curves derived from pure standards of tocopherol. The peaks of the tocopherol standards $(\alpha-, \beta, \gamma-$, and $\delta$ - tocopherol) were distinguished by their retention times. To determine tocopherol contents of experimental samples, standard curve was calibrated in accordance with the corresponding peaks of individual tocopherol derivatives. Tocopherol contents were expressed in mg per $g$ of sample, and the total amount of tocopherol was calculated as the sum of $\alpha$ - and $\gamma$-tocopherol.

\section{Determination of Fatty Acid Composition and Content}

Fatty acids (FAs) were analyzed according to the protocol described by Chen et al. (2012) with slight modifications. Approximately $200 \mathrm{mg}$ of leaf samples were ground in a 12$\mathrm{mL}$ screw-top glass tube having $5 \mathrm{ml}$ of extraction solution (chloroform/isopropanol, 2:1, v/v), followed by incubation at $80^{\circ} \mathrm{C}$ for $2 \mathrm{~h}$. Upon cooling down the samples to room temperature, $1 \mathrm{ml}$ of $\mathrm{n}$-hexane and $2 \mathrm{ml}$ of $\mathrm{NaCl}$ solution $(0.9 \%)$ were added to the tubes. The specimens were centrifuged at $2,300 \mathrm{rpm}$ for $5 \mathrm{~min}$. The supernatant $(1 \mathrm{ml})$ was used to analyze the FA components on GC-FID. The samples $(2 \mu \mathrm{l})$ were auto-injected into the gas chromatograph (GC, 6890N, Agilent, United States) system, having a fused silica capillary column RtxWax $(30 \mathrm{~m} \times 0.25 \mathrm{~mm} \times 0.50 \mu \mathrm{m}$, Restek, United States $)$ and FID detector. Initially, the column temperature was set to $160^{\circ} \mathrm{C}$ for $1 \mathrm{~min}$, following a gradual increase to $240^{\circ} \mathrm{C}$ at the rate of $4^{\circ} \mathrm{C} / \mathrm{min}$, and maintained for $16 \mathrm{~min}$.

\section{Quantitative Real-Time PCR Analyses}

About $100 \mathrm{mg}$ of leaf tissues were crushed, and total RNA was extracted using Miniprep kit, following the manufacturer's instructions. RNeasy Mini Kit (Qiagen, Hilden, Germany) was used to remove genomic DNA. ReverTra AceqPCR RT kit (Toyobo, Japan) was utilized to synthesize cDNA. Based on mRNA or expressed sequence tag (EST), gene-specific primers were designed for qRT-PCR. SYBR Green PCR Master Mix (Applied Biosystems) was used to amplify the PCR products, in triplicate, in $25 \mu \mathrm{l}$ qRT-PCRs in an iCycleriQ ${ }^{\mathrm{TM}}$ 96-well real-time PCR detection system (Bio-Rad, Hercules, CA, United States). PCR conditions were as follows: denaturation at $95^{\circ} \mathrm{C}$ for $3 \mathrm{~min}$; 40 cycles of denaturation at $95^{\circ} \mathrm{C}$ for $30 \mathrm{~s}$; annealing at $58^{\circ} \mathrm{C}$ for $30 \mathrm{~s}$; extension at $72^{\circ} \mathrm{C}$ for $30 \mathrm{~s}$. Threshold cycle values were calculated by employing the software provided with the 
PCR machine and mRNA levels were quantified by following the method described by Livak and Schmittgen (2001).

\section{Subcellular Analysis by Transmission Electron Microscopy (TEM)}

Fresh leaf sections $\left(\sim 1 \mathrm{~mm}^{2}\right)$ were excised at 9 days after treatment (DAT) from the topmost fully expanded leaves of plants and processed for TEM studies. Samples were fixed in $2.5 \%$ glutaraldehyde $(\mathrm{v} / \mathrm{v})$ overnight and washed three times with $0.1 \mathrm{M}$ SPB (sodium phosphate buffer, $\mathrm{pH}$ 7.0). The specimens were post-fixed in $1 \%$ osmium tetroxide $\left(\mathrm{OsO}_{4}\right)$ for $1 \mathrm{~h}$ and washed with $0.2 \mathrm{M} \mathrm{SPB}(\mathrm{pH} \mathrm{7.2)}$ for $1-2 \mathrm{~h}$. Dehydration was carried out in a graded series of ethanol (50, 60, 70, 80, 90, 95 , and $100 \%)$ and acetone (100\%). The samples were then infiltrated and embedded in Spurr's resin. Ultrathin sections $(80 \mathrm{~nm})$ were prepared and mounted on copper grids and viewed under transmission electron microscope (JEOL TEM-1230EX) at an accelerating voltage of $60.0 \mathrm{kV}$.

\section{Statistical Analysis}

Data were statistically analyzed using MSTAT-C software version 2.10 and expressed as means \pm standard error (SE). Data were subjected to one-way ANOVA, and LSD test was used to compare the treatments at $P \leq 0.01$ or $P \leq 0.05$ (Steel and Torrie, 1980). Figures were prepared using OriginPro v7.5 (OriginLab, Northampton, MA, United States) software.

\section{RESULTS}

\section{Photosynthetic Pigment Composition}

Chlorophyll is the main component of green plants. The amount and composition of chlorophyll differ from genotype to genotype and also depend on environmental conditions. In the present study, total chlorophyll content of Zheyou-50 was $52.3 \mathrm{mg} \mathrm{g}^{-1}$ FW, which was considerably higher than that of Jiu-Er-13XI (38.1 $\mathrm{mg} \mathrm{g}^{-1} \mathrm{FW}$ ). Chl a and Chl b contents also varied between two genotypes. Zheyou-50 and Jiu-Er-13XI contained 32.1 and $23.5 \mathrm{mg} \mathrm{g}^{-1} \mathrm{FW} \mathrm{chl} \mathrm{a}$, and 21.1 and $14.6 \mathrm{mg} \mathrm{g}^{-1} \mathrm{FW} \mathrm{chl} \mathrm{b}$, respectively (Table 1 ). Cd treatment adversely affected pigment contents in both genotypes. Chl a, chl b, and total chl decreased by $32.35,21.27$, and $30 \%$ respectively, with respect to control treatment. The detrimental effect of Cd became prominent with increasing treatment time duration. Total chlorophyll content reduced by 10 and $20 \%$ at 6 DAT and 9 DAT, respectively, compared to 3 DAT (Table 1). All sole factors were significantly different for photosynthetic pigment composition and content.

Interactive effect showed a conspicuous decline in chlorophyll content in both genotypes subjected to $\mathrm{Cd}$ stress. However, the decrease was more pronounced in Jiu-Er-13XI than in Zheyou-50. Jiu-Er-13XI showed 47.9, 34.10, and 43\% reduction in chl a, chl b, and total chlorophyll, respectively, compared to control treatment (Figure 1). However, both genotypes showed a non-significant decrease in pigment content with increase in treatment timing (Supplementary Table S2).
TABLE 1 | Sole effect of genotype, treatment, and timings on photosynthetic pigments in rapeseed.

\begin{tabular}{|c|c|c|c|}
\hline & $\begin{array}{c}\text { Chl a [mg/g fresh } \\
\text { weight (FW)] }\end{array}$ & Chl b (mg/g FW) & Chla + b (mg/g FW) \\
\hline \multicolumn{4}{|l|}{ Genotypes } \\
\hline Jiu-Er-13XI & $23.5 \pm 2.07 b$ & $14.6 \pm 0.99 b$ & $38.1 \pm 2.95 b$ \\
\hline Zheyou-50 & $32.1 \pm 1.15 \mathrm{a}$ & $21.1 \pm 0.88 a$ & $52.3 \pm 2.03 \mathrm{a}$ \\
\hline Significance & $\star \star$ & ** & $\star \star$ \\
\hline \multicolumn{4}{|l|}{ Treatments } \\
\hline $\mathrm{Ck}$ & $33.2 \pm 1.08 \mathrm{a}$ & $20.0 \pm 0.85 a$ & $53.2 \pm 1.79 \mathrm{a}$ \\
\hline $\mathrm{Cd}$ & $\begin{array}{c}22.4 \pm 1.79 b \\
(-32.35 \%)\end{array}$ & $\begin{array}{c}15.7 \pm 1.32 b \\
(-21.27 \%)\end{array}$ & $\begin{array}{c}37.2 \pm 2.83 b \\
(-30 \%)\end{array}$ \\
\hline Significance & $\star \star$ & ** & $\star *$ \\
\hline \multicolumn{4}{|l|}{ Timings } \\
\hline 3DAT & $31.1 \pm 2.10 \mathrm{a}$ & $19.3 \pm 1.31$ & $50.4 \pm 3.19 a$ \\
\hline 6DAT & $\begin{array}{l}27.1 \pm 2.54 \mathrm{~b} \\
\quad(-12 \%)\end{array}$ & $\begin{array}{c}17.9 \pm 1.47 \\
(-7.33 \%)\end{array}$ & $\begin{array}{c}45.0 \pm 3.72 \mathrm{ab} \\
(-10.7 \%)\end{array}$ \\
\hline 9DAT & $\begin{array}{l}25.2 \pm 2.35 b \\
\quad(-18 \%)\end{array}$ & $\begin{array}{c}16.4 \pm 1.66 \\
(-14.84 \%)\end{array}$ & $\begin{array}{c}40.1 \pm 3.83 b \\
(-20.36 \%)\end{array}$ \\
\hline Significance & $\star \star$ & ns & $\star \star$ \\
\hline
\end{tabular}

DAT, days after treatment; ns, non-significant. ${ }^{* *}$ Significant at $P \leq 0.01$; numbers in parenthesis show percent increase (+) or decrease (-).

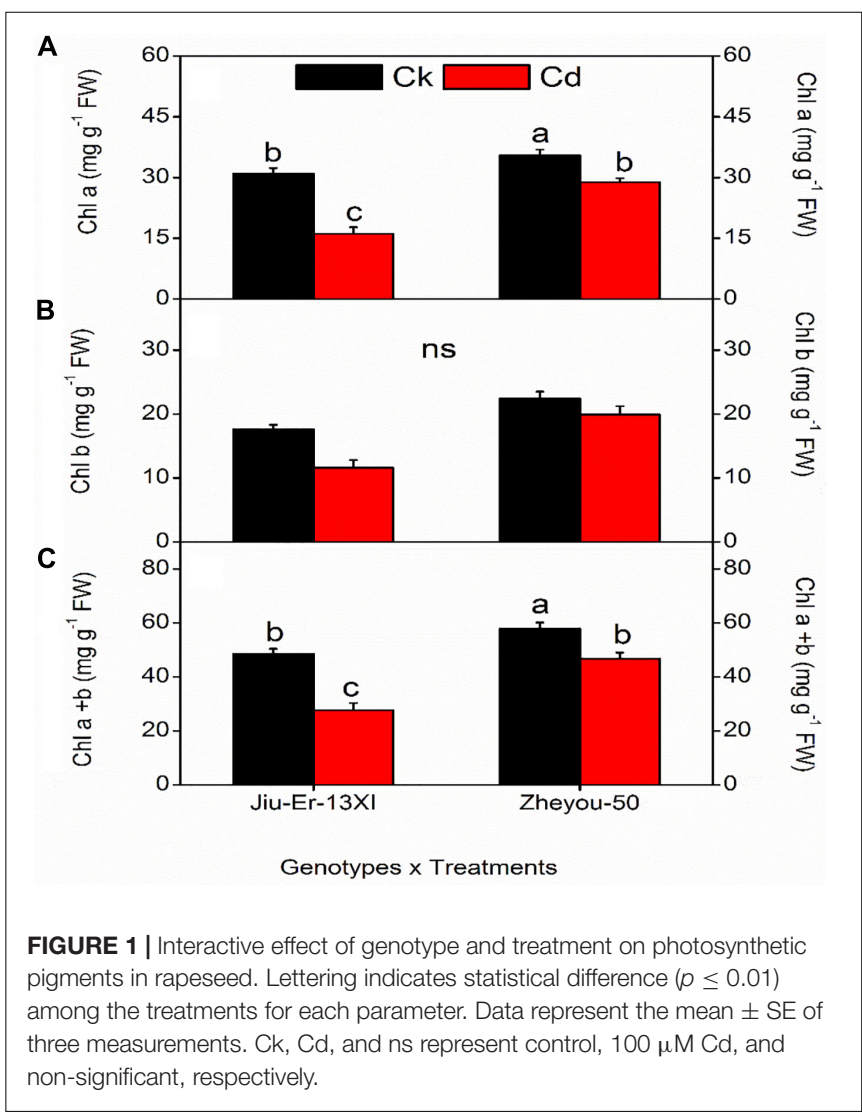

\section{Cadmium Accumulation and MDA Content}

Malondialdehyde is the oxidative product of membrane lipids and its accumulation in plant tissues is an indicator of lipid 
peroxidation during environmental stresses. In the present study, Cd-treated plants accumulated up to 53\% higher MDA content than the Cd-untreated ones, showing the deleterious effects of Cd on membrane lipids. Nonetheless, Zheyou-50 exhibited tolerance to $\mathrm{Cd}$ by accumulating less amount of MDA (18.72 nM $\mathrm{g}^{-1}$ FW) than Jiu-Er-13XI (22.27 nM g $\left.\mathrm{g}^{-1} \mathrm{FW}\right)$. Maximum increase $(63.15 \%)$ in MDA content was seen at 9 DAT, compared with 3 DAT, suggesting a rise in oxidative stress on membrane lipids with increasing time duration (Table 2). Interactive effects for MDA accumulation are presented in Supplementary Table S3 and Figure 2. Cd treatment deleteriously affected JiuEr-13XI and showed 72\% higher MDA content than the control treatment. Conversely, Zheyou-50 depicted only 32\% increase in MDA content under cd treatment compared to control. Moreover, 43.49, 58.63, and 46.93\% increase was recorded for MDA accumulation at 3, 6, and 9 DAT, respectively, under Cd treatment. Roots are in direct contact with metals whether in the soil or in a hydroponic system. In the present study, root and shoot accumulated 15.7 and $0.17 \mathrm{mg} \mathrm{Cd} / \mathrm{g}$ DW, respectively, under $\mathrm{Cd}$ treatment. Cd accumulation significantly increased with treatment timings as $9.9 \mathrm{mg} / \mathrm{g}$ DW (root) and $0.11 \mathrm{mg} / \mathrm{g}$ DW (shoot) Cd content was recorded at 9 DAT, which was considerably higher than that observed after 3 days of treatment (Table 2). Under Cd treatment, Jiu-Er-13XI plants accumulated $\mathrm{Cd}$ at the rate of 0.019 and $17.30 \mathrm{mg} / \mathrm{g} \mathrm{DW}$ in shoot and root, respectively. However, Zheyou-50 showed only 0.017 and $14 \mathrm{mg} / \mathrm{g}$ DW $\mathrm{Cd}$ in shoot and root, under Cd treatment, respectively (Figure 2). Jiu-Er-13XI exhibited $89.80 \%$, while Zheyou-50 showed only $48 \%$ rise in Cd accumulation at 9 DAT compared to 3 DAT.

\section{Accumulation of Reactive Oxygen Species}

Reactive oxygen species (ROS), produced during oxidative stress, are harmful to plants. ROS, especially hydrogen peroxide

TABLE 2 | Sole effect of genotype, treatment and timings on root shoot cadmium (Cd) accumulation and leaf malondialdehyde (MDA) content in rapeseed.

\begin{tabular}{|c|c|c|c|}
\hline Factors & $\begin{array}{c}\text { Cd (root) } \\
\text { (mg/g DW) }\end{array}$ & $\begin{array}{l}\text { Cd (shoot) } \\
\text { (mg/g DW) }\end{array}$ & MDA (nM g $\left.g^{-1} \mathrm{FW}\right)$ \\
\hline \multicolumn{4}{|l|}{ Genotypes } \\
\hline Jiu-Er-13XI & $8.69 \pm 2.24 \mathrm{a}$ & $0.12 \pm 0.03 \mathrm{a}$ & $22.27 \pm 1.89 a$ \\
\hline Zheyou-50 & $7.14 \pm 1.77 b$ & $0.05 \pm 0.01 b$ & $18.05 \pm 1.31 b$ \\
\hline Significance & $\star \star$ & $\star \star$ & $\star \star$ \\
\hline \multicolumn{4}{|l|}{ Treatments } \\
\hline $\mathrm{Ck}$ & $0.08 \pm 0.006 b$ & $0.007 \pm 0.0007 \mathrm{~b}$ & $15.92 \pm 0.94 b$ \\
\hline $\mathrm{Cd}$ & $15.76 \pm 1.02 \mathrm{a}$ & $0.17 \pm 0.02 \mathrm{a}$ & $24.40 \pm 1.68 \mathrm{a}(+53.18 \%)$ \\
\hline Significance & $\star \star *$ & $\star \star$ & $\star \star$ \\
\hline \multicolumn{4}{|l|}{ Timings } \\
\hline 3DAT & $5.88 \pm 1.78 c$ & $0.05 \pm 0.02 c$ & $15.67 \pm 1.15 \mathrm{c}$ \\
\hline 6DAT & $7.90 \pm 2.39 b$ & $0.09 \pm 0.03 b$ & $19.25 \pm 1.81 \mathrm{~b}(+22.9 \%)$ \\
\hline 9DAT & $9.97 \pm 3.08 \mathrm{a}$ & $0.11 \pm 0.03 a$ & $25.56 \pm 2.08 \mathrm{a}(+63.15 \%)$ \\
\hline Significance & ** & ** & $\star *$ \\
\hline
\end{tabular}

DAT, days after treatment; $n s$, non-significant. **Significant at $P \leq 0.01$.

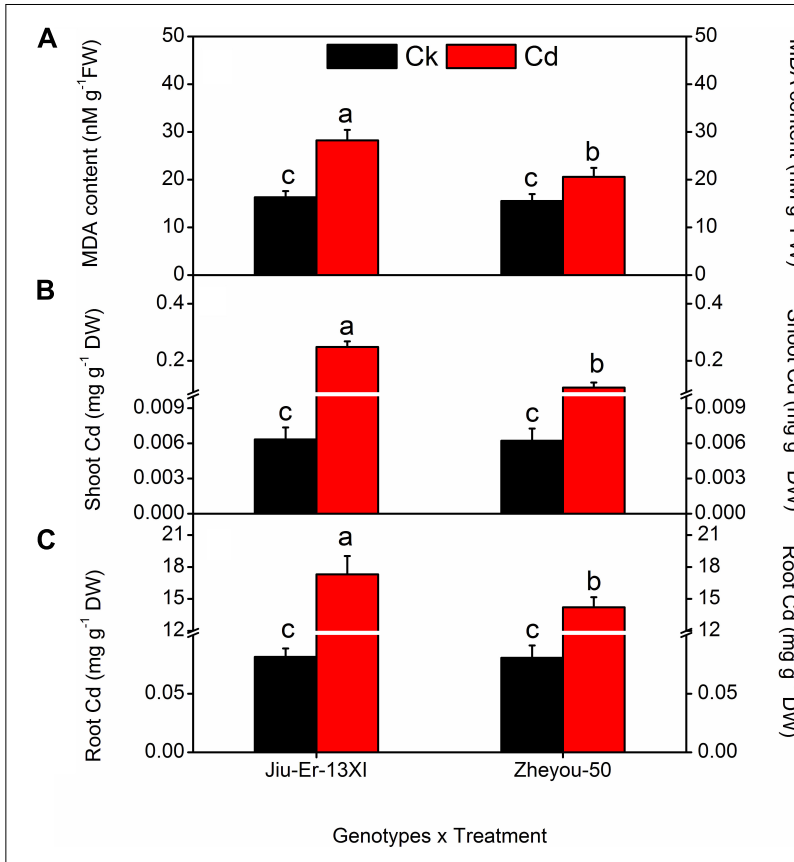

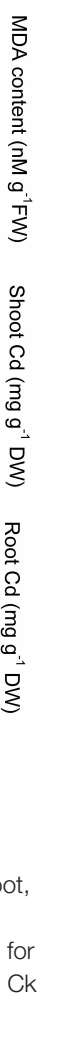

FIGURE 2 | Interactive effects of genotypes and treatments on root, shoot, Cd accumulation, and leaf malondialdehyde (MDA) content in rapeseed. Lettering indicates statistical difference $(p \leq 0.01)$ among the treatments for each parameter. Data represent the mean \pm SE of three measurements. CK and Cd represent control and $100 \mu \mathrm{M} \mathrm{Cd}$, respectively.

$\left(\mathrm{H}_{2} \mathrm{O}_{2}\right)$ and superoxide radicals $\left(\mathrm{O}_{2}{ }^{\bullet}\right)$, generated during stresses directly attack membrane lipids and compromise the integrity of the membrane system. In the current study, $\mathrm{H}_{2} \mathrm{O}_{2}$ and $\mathrm{O}_{2}{ }^{\bullet}$ contents increased by 36.30 and $18.68 \%$, respectively, under Cd stress compared to the control treatment. Increase in treatment duration elevated the accumulation of ROS. At $48 \mathrm{HAT}, \mathrm{H}_{2} \mathrm{O}_{2}$ and $\mathrm{O}_{2}{ }^{\bullet}$ contents increased up to 32 and $14.20 \%$ compared to 12 HAT (Table 3 ).

Moreover, Jiu-Er-13XI was more severely affected by $\mathrm{Cd}$ stress than Zheyou-50. Jiu-Er-13XI showed 50 and $25.70 \%$, while Zheou-50 exhibited only 20 and $11.32 \%$ increase in $\mathrm{H}_{2} \mathrm{O}_{2}$ and $\mathrm{O}_{2} \bullet$ contents, respectively, in comparison with their respective control treatments (Figure 3). Treatment duration aggravated the outcomes of Cd stress on both genotypes. However, the impact was more pronounced in Jiu-Er-13XI, with a $43 \%$ increase in $\mathrm{H}_{2} \mathrm{O}_{2}$ content at $48 \mathrm{HAT}$, compared to $12 \mathrm{HAT}$ (Supplementary Table S4).

\section{Expression of Tocopherol Biosynthesis Genes}

Tocopherol biosynthesis pathway consists of six genes. Expression of these genes was measured at 12, 24, and 48 HAT. A significant difference was seen in the expression of all genes, except BnPDS1, in both genotypes. Moreover, Cd stress increased the expression of all genes compared to control treatment. An average increase of $52.7 \%$ was seen in BnVTE4, which codes for $\alpha$-tocopherol. The increase in gene expression was time dependent (Table 4). Cadmium treatment affected 
TABLE 3 | Sole effects of genotypes, treatments, and timings on leaf reactive oxygen species (ROS) accumulation in rapeseed.

\begin{tabular}{|c|c|c|}
\hline & $\mathrm{H}_{2} \mathrm{O}_{2}\left(\mu \mathrm{mol} \mathrm{g}{ }^{-1} \mathrm{FW}\right)$ & $\left.\mathrm{O}_{2}^{-}(\mathrm{nmol} \mathrm{m})^{-1} \mathrm{~g}^{-1} \mathrm{FW}\right)$ \\
\hline \multicolumn{3}{|l|}{ Genotypes } \\
\hline Jiu-Er-13XI & $42.7 \pm 2.7 \mathrm{a}$ & $61.1 \pm 2.0 \mathrm{a}$ \\
\hline Zheyou-50 & $33.2 \pm 1.2 \mathrm{~b}$ & $54.6 \pm 1.2 \mathrm{~b}$ \\
\hline Significance & ** & $\star \star$ \\
\hline \multicolumn{3}{|l|}{ Treatments } \\
\hline $\mathrm{Ck}$ & $32.1 \pm 1.1$ & $52.9 \pm 1.0 \mathrm{~b}$ \\
\hline $\mathrm{Cd}$ & $43.8 \pm 2.5 a(+36 \%)$ & $62.8 \pm 1.7 \mathrm{a}(+18 \%)$ \\
\hline Significance & $\star \star$ & $\star *$ \\
\hline \multicolumn{3}{|l|}{ Timings } \\
\hline 12HAT & $32.4 \pm 1.7 b$ & $53.1 \pm 1.7 b$ \\
\hline 24HAT & $38.5 \pm 2.9 a(+18 \%)$ & $59.7 \pm 1.9 a(+12 \%)$ \\
\hline $48 \mathrm{HAT}$ & $43.0 \pm 3.4 \mathrm{a}(+32 \%)$ & $60.7 \pm 2.6 \mathrm{a}(+14 \%)$ \\
\hline Significance & ** & $\star *$ \\
\hline
\end{tabular}

HAT, hours after treatment. ${ }^{*}$ Significant at $P \leq 0.01$.

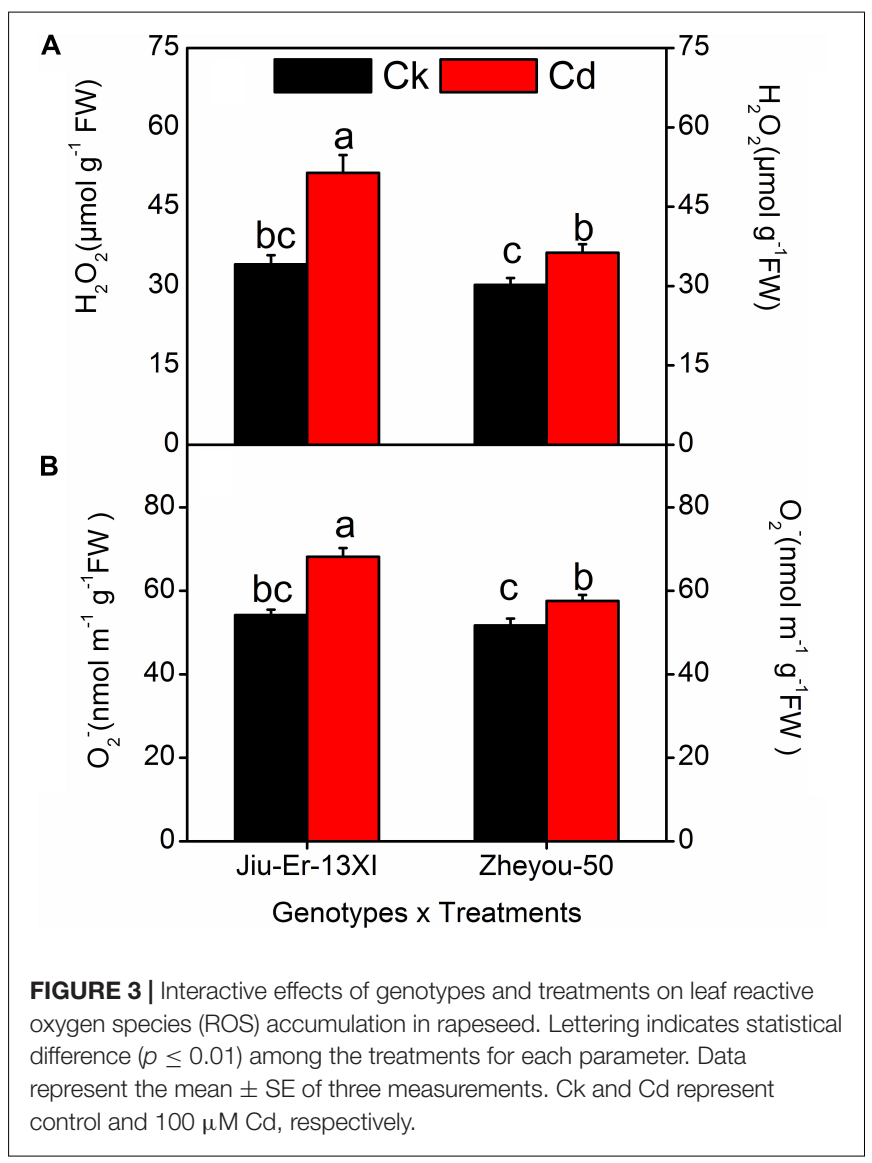

the expression of tocopherol biosynthesis pathway genes in different manners in both genotypes. A prominent increase in BnVTE4 (87\%) and BnVTE5 (65\%) was observed in Zheyou-50 and Jiu-Er-13XI, respectively, under Cd stress, indicating the accumulation of $\alpha$-tocopherol in Zheyou-50 and degradation of chlorophyll in Jiu-Er-13XI (Figure 4). Besides, a significant interaction was observed between genotypes and treatment as well as treatment and time duration except for BnVTE1 (Supplementary Table S5).

\section{Fatty Acid Contents and Composition}

Cadmium stress affected fatty acid contents and composition in a genotype-dependent manner. Compared with normal growth conditions, Jiu-Er-13XI showed about 21\% decrease, while Zheyou-50 depicted $3.40 \%$ increase in total fatty acid content under Cd stress (Figure 5). Cd stress caused a reduction in 18:2 and 18:3 fatty acid contents of Jiu-Er-13XI by 41.11 and $49.21 \%$, respectively, indicating a detrimental effect of $\mathrm{Cd}$ on polyunsaturated fatty acids (PUFA). In contrast, no such adversity was recorded for Zheyou-50. Instead, a 10.20 and $3.34 \%$ increase was detected in $18: 2$ and $18: 3$ fatty acids, respectively, suggesting a normal metabolism in this genotype. Sole and interactive effects are also presented in Table $\mathbf{5}$ and Supplementary Table S6.

\section{Tocopherol Contents and Composition}

Jiu-Er-13XI and Zheyou-50 showed a differential response to $\mathrm{Cd}$ in terms of tocopherol composition. Jiu-Er-13XI revealed 2.82, 0.08, and $3.07 \mathrm{mg} \mathrm{g} \mathrm{g}^{-1} \mathrm{FW}$ of alpha, gamma, and total tocopherol, respectively, whereas Zheyou-50 exhibited a higher concentration of alpha (4.32 $\left.\mathrm{mg} \mathrm{g}^{-1} \mathrm{FW}\right)$, gamma (0.09 $\left.\mathrm{mg} \mathrm{g}^{-1} \mathrm{FW}\right)$ and total tocopherol (4.42 $\mathrm{mg} \mathrm{g}^{-1} \mathrm{FW}$ ) than its counterpart. On average basis, $\mathrm{Cd}$ increased alpha and total tocopherol by 22.11 and $25.31 \%$, respectively, while decreased gamma tocopherol content by $27.44 \%$ with respect to control. Moreover, treatment duration also enhanced the total tocopherol by 19.69 and $44.05 \%$ at 3 DAT and 9 DAT, respectively, with reference to the control treatment (Table 6). Considering interactive effects, Cd treatment increased total and $\alpha$-tocopherol contents in both genotypes, while it decreased gamma tocopherol. However, the increase was prominent in Zheyou-50 as it accumulated 45.33 and $47.43 \%$ higher total and $\alpha$-tocopherol under $\mathrm{Cd}$ stress than the control treatment. Conversely, Jiu-Er-13XI accumulated only 22.61 and $32.74 \%$ higher content of alpha and total tocopherol under Cd treatment than the normally grown plants (Figure 6). Treatment duration also induced the accumulation of $\alpha$-tocopherol, which was higher (46.74\%) in Zheyou-50 than in Jiu-Er-13XI (29.30\%), with reference to their respective control treatments. The increase in total tocopherol was directly proportional to treatment duration. After 9 days of treatment, total and $\alpha$-tocopherol increased by 41.86 and $36.20 \%$, respectively. Interestingly, increase in $\alpha$-tocopherol was accompanied by a corresponding decline in $\gamma$-tocopherol. Cd treatment decreased $\gamma$-tocopherol by 35.16 and $28.16 \%$ in Zheyou-50 and Jiu-Er-13XI, respectively. After 9 days of treatment, the decrease was considerably prominent in Zheyou-50 (51.08\%), suggesting the impact of time duration on the fate of $\gamma$-tocopherol (Supplementary Table S7).

\section{Subcellular Study}

Molecular and biochemical changes observed in rapeseed genotypes under $\mathrm{Cd}$ stress reflected at subcellular level as well. The leaf cells of the Jiu-Er-13XI and Zheyou-50 control plants were metabolically active, as suggested by the presence 
TABLE 4 | Sole effects of genotypes, treatments, and timings on tocopherol (Toc) biosynthesis genes.

\begin{tabular}{|c|c|c|c|c|c|c|}
\hline & BnVTE1 & BnVTE2 & BnVTE3 & BnVTE4 & BnVTE5 & BnPDS1 \\
\hline \multicolumn{7}{|l|}{ Genotypes } \\
\hline Jiu-Er-13XI & $1.11 \pm 0.11$ & $0.93 \pm 0.1 b$ & $1.38 \pm 0.16 a$ & $0.96 \pm 0.05 b$ & $1.6 \pm 0.1 \mathrm{a}$ & $6.4 \pm 1.4$ \\
\hline Zheyou-50 & $1.09 \pm 0.08$ & $1.98 \pm 0.3 \mathrm{a}$ & $0.84 \pm 0.07 b$ & $1.17 \pm 0.10 \mathrm{a}$ & $0.8 \pm 0.06 b$ & $7.0 \pm 1.4$ \\
\hline Significance & Ns & $\star \star$ & $\star \star$ & $\star \star$ & $* \star$ & ns \\
\hline \multicolumn{7}{|l|}{ Treatments } \\
\hline Ck & $0.89 \pm 0.06 b$ & $1.28 \pm 0.23 b$ & $0.86 \pm 0.05 b$ & $0.84 \pm 0.05 b$ & $1.06 \pm 0.07 b$ & $3.0 \pm 0.4 b$ \\
\hline $\mathrm{Cd}$ & $1.31 \pm 0.09 a$ & $1.63 \pm 0.28 a$ & $1.36 \pm 0.17 \mathrm{a}$ & $1.29 \pm 0.07 \mathrm{a}$ & $1.37 \pm 0.17 a$ & $10.3 \pm 1.5 a$ \\
\hline Significance & ** & $\star \star$ & $\star \star$ & ** & $\star \star$ & $\star \star$ \\
\hline \multicolumn{7}{|l|}{ Timing } \\
\hline ЗНАТ & $1.15 \pm 0.07$ & $0.89 \pm 0.08 b$ & $1.11 \pm 0.09$ & $1.17 \pm 0.07 \mathrm{a}$ & $1.17 \pm 0.16$ & $3.3 \pm 1.1 \mathrm{c}$ \\
\hline 6HAT & $1.09 \pm 0.15$ & $0.98 \pm 0.17 b$ & $1.08 \pm 0.11$ & $0.93 \pm 0.1 \mathrm{ab}$ & $1.23 \pm 0.13$ & $5.7 \pm 1.0 b$ \\
\hline 9HAT & $1.07 \pm 0.11$ & $2.50 \pm 0.34 \mathrm{a}$ & $1.14 \pm 0.27$ & $1.09 \pm 0.1 b$ & $1.26 \pm 0.21$ & $11.0 \pm 0.02 a$ \\
\hline Significance & Ns & $\star \star$ & ns & $\star \star$ & Ns & $\star \star$ \\
\hline
\end{tabular}

HAT, hours after treatment; $n s$, non-significant. * Significant at $P \leq 0.01$.

of well-developed chloroplasts with the normal shape and size. There were no starch granules in cells of both genotypes under control treatment, indicating a normal carbohydrate metabolism. Furthermore, the structure of granal and stromal lamella remained intact under normal growth environment (Figures 7A,C). Contrarily, subcellular structure of Cd-treated plants, especially Jiu-Er-13XI (low oil rapeseed genotype), was severely affected by stress. The chloroplast structure changed from normal elongated to big round-shaped one. The thylakoid membrane system was completely destroyed by $\mathrm{Cd}$ stress. Accumulation of starch granules in chloroplast is a clear sign of disrupted starch metabolism. Increase in number and size of plastoglobules suggests the accumulation of tocopherols under stress (Figures 7B,D). Unlike Jiu-Er-13XI, the genotype with high oil content (Zheyou-50) showed a moderate level of Cd-induced damage to chloroplast structure. The thylakoid membrane network showed comparatively better arrangements, with no starch granules, showing undisturbed carbohydrate metabolism under Cd stress.

\section{DISCUSSION}

Comprehensive study on tolerance of plants to Cd stress is of utmost importance to elucidate the underlying mechanisms to develop Cd-tolerant genotypes. Ability of plants to detoxify ROS is one of the main strategies to combat heavy metal-induced oxidative stress. Tocopherols are regarded as the non-enzymatic component of the plant defense system and play major roles in protecting plants against stresses at cellular and subcellular level (Collakova and DellaPenna, 2003; Li et al., 2010). The current investigation is focused on illuminating the role of tocopherols in response to oxidative stress, induced by $\mathrm{Cd}$, in two oilseed rape genotypes, differing in fatty acid content.

Current study indicates $\mathrm{Cd}$ accumulation in roots and its translocation to upper parts of plants in both genotypes. However, the degree of absorption and translocation is higher in Jiu-Er-13XI (low seed oil content) than in Zheyou-50 (high seed oil content), suggesting the tolerance of Zheyou-50 to Cd stress.
Usually, tolerant genotypes either inhibit the absorption of heavy metals via roots or restrict their translocation to the leaves. The effect of Cd on photosynthetic pigments is well documented (Ali et al., 2015). Cd is believed to replace metals in metal-containing enzymes, e.g., substituting Ca ion in PSII leads to the inhibition of water splitting systems. Damage to structure of chloroplast, reduction in chlorophyll synthesis and its deterioration are the major reasons for reduction in chlorophyll content (LópezMillán et al., 2009). The net loss of chlorophyll was much higher in Jiu-Er-13XI than in Zheyou-50. The main reason behind this tolerance is the reduced absorption and restricted translocation of Cd ions in Zheyou-50.

Accumulation of ROS in Cd-treated plants has been reported in the literature (Pathak and Khandelwal, 2006; Zhou et al., 2009). Though Cd cannot directly generate free radicals, it produces ROS indirectly by increasing the free Fe-concentration, possibly via replacement in various proteins (Scholz et al., 1990; Dorta et al., 2003). Quantification of $\mathrm{H}_{2} \mathrm{O}_{2}$ and $\mathrm{O}_{2}{ }^{-}$in this study indicates an immediate accumulation of ROS upon $\mathrm{Cd}$ exposure. The degree of accumulation is treatment duration and genotype dependent, as Zheyou-50 accumulated less ROS than Jiu-Er-13XI. Upregulation of BnVTE5 in Jiu-Er-13XI shows the increased degradation of chlorophyll by ROS.

Polyunsaturated fatty acids, such as linolenic acid and linoleic acid in membrane lipids are very sensitive to oxidation caused by Cd-induced ROS (Frankel, 2005). Current experiment reveals a decline in total fatty acid content of Cd-treated plants of JiuEr-13XI, compared to the normally grown plants. This reduction in total fatty acids is ascribed to decrease in 18:2 and 18:3 fatty acids in Cd-treated Jiu-Er-13XI plants. Stressed plants of JiuEr-13XI indicate increase in content of other fatty acids like, $16: 0$, 18:0, and 18:1, suggesting an inhibition in desaturation ability of enzymes. Contrary to that, no such effect on fatty acid composition of Zheyou-50 plants is observed. Instead, considerable enhancement in total fatty acid content under $\mathrm{Cd}$ treatment suggests the tolerance of this genotype to $\mathrm{Cd}$ stress. The increase in expression level of BnVTE4 in Zheyou50 may protect PUFA under stressed environment. In a current investigation, decrease in 18:2 and 18:3 fatty acid contents 


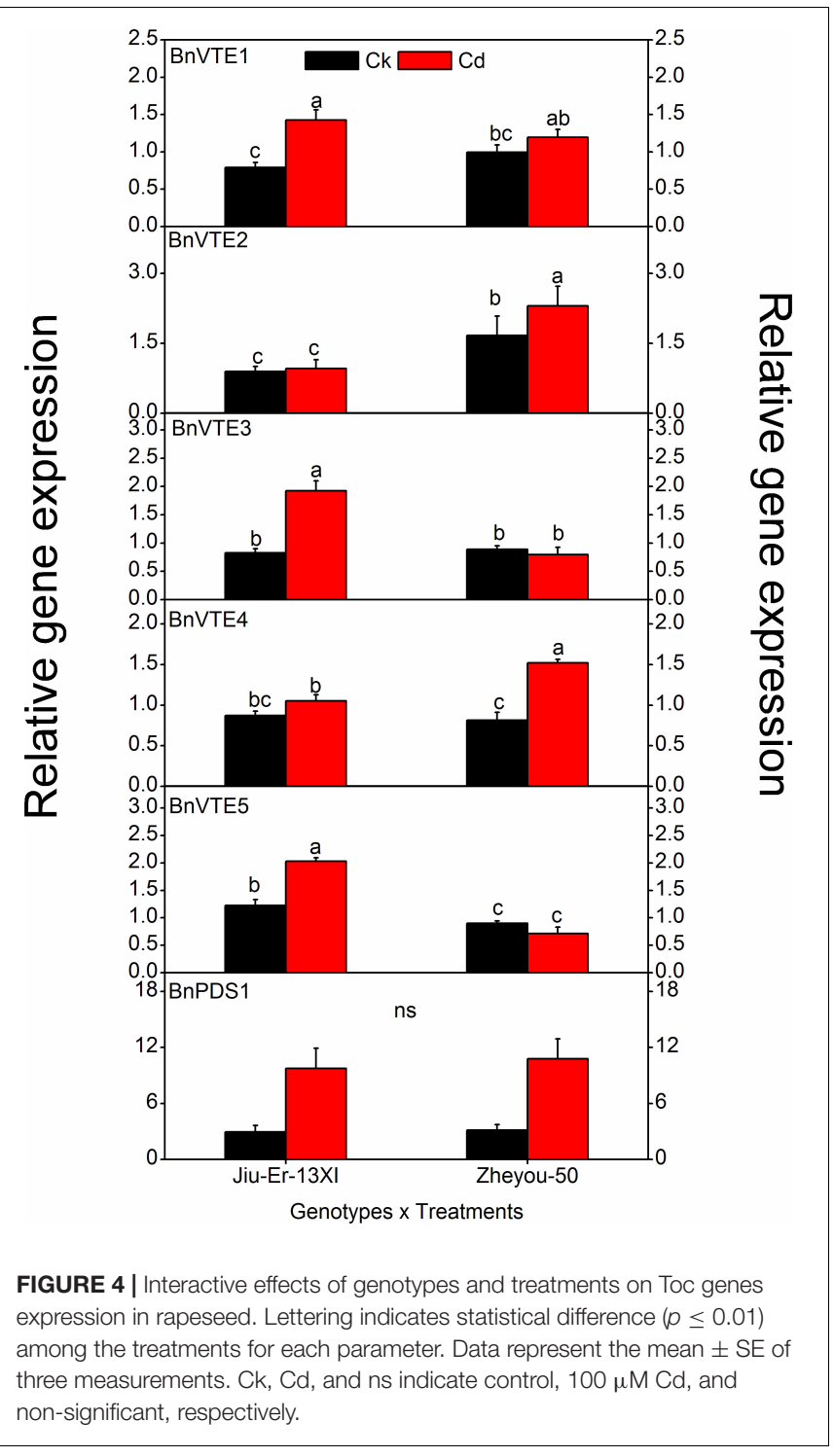

of Jiu-Er-13XI is accompanied by the accumulation of MDA. MDA is the product of oxidation of 18:3 fatty acid, which is regarded as an important indicator of fatty acid oxidation under stress (Sattler et al., 2003). With increase in treatment duration, marked increase can be seen in MDA content. Conversely, MDA accumulation is low in Zheyou-50 because Cd stress had no such effects on the fatty acid composition of this genotype.

A study of anatomical disorders under a stressful environment is highly important to understand the tolerance mechanism of plants at subcellular level. Studies on barley (Wang et al., 2011) and tomato (Gratão et al., 2009) indicate that chloroplast is highly vulnerable to $\mathrm{Cd}$ stress. The present study reveals a severe damage to chloroplast structure of plants of Jiu-Er13XI under Cd stress. The damaging effect can be explained as disruption in chloroplast structure (Borges et al., 2004), with completely deformed thylakoid membranes (Vijaranakul et al., 2001). Abnormal chloroplast, having reduced amounts of

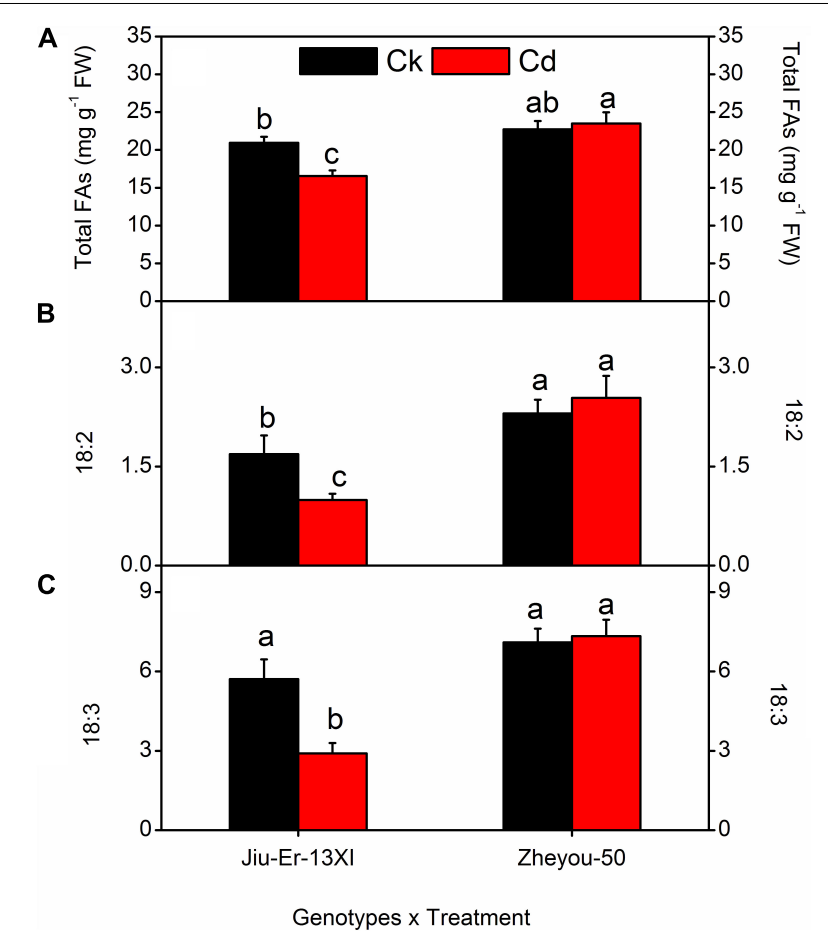

FIGURE 5 | Interactive effects of genotypes and treatments on leaf fatty acid content and composition in rapeseed. Lettering indicates statistical difference $(p \leq 0.01)$ among the treatments for each parameter. Data represent the mean \pm SE of three measurements. Ck and Cd represent control and $100 \mu \mathrm{M}$ $\mathrm{Cd}$, respectively.

chlorophyll, is unlikely to possess surplus energy. Therefore, the presence of starch granules in Jiu-Er-13XI genotype indicates the incapability of chloroplasts to metabolize reserve carbohydrates (Uzunova and Popova, 2000), indicating the vulnerability of this genotype to $\mathrm{Cd}$. In contrast, Zheyou-50 is not much affected by Cd stress.

Tocopherols are vitamin E group of lipid-soluble compounds having multifunctional properties. Tocopherols are believed to protect PUFA from ROS, produced during oxidative stress either by quenching superoxide radicals or by terminating the chain reaction (Sattler et al., 2004b; Krieger-Liszkay, 2005). Having said that tocopherols are produced by the oxygenic organisms and are an essential component of human nutrition, their function is not well investigated in plants. The reason behind the scarcity of literature could be the disappointing results obtained in certain studies where complete absence of tocopherol did not show any significant influence on plant growth and metabolism (Havaux et al., 2005; Maeda et al., 2005). Therefore, the role of tocopherol in mitigating oxidative damage remained unexplored. Instead, its role in other processes like transport of sugars, cellular signaling, and seed germination and dormancy are reported (Sattler et al., 2004b). However, with the advent of mutation and transgenic techniques in Arabidopsis and Synechocystis sp. PCC6803, study on functions of tocopherols became possible by eliminating (Schledz et al., 2001) or increasing the concentration of tocopherol (Collakova and DellaPenna, 2001; 
TABLE 5 | Sole effects of genotypes, treatments, and timings on leaf fatty acid (FA) content and composition in rapeseed.

\begin{tabular}{|c|c|c|c|c|c|c|}
\hline & $16: 0$ & 18:0 & $18: 1$ & $18: 2$ & $18: 3$ & Total FA \\
\hline \multicolumn{7}{|l|}{ Genotypes } \\
\hline Jiu-Er-13XI & $3.4 \pm 0.09$ & $1.39 \pm 0.11$ & $3.41 \pm 0.18$ & $1.34 \pm 0.16$ & 4.3 & $18.7 \pm 0.74$ \\
\hline Zheyou-50 & $3.3 \pm 0.16$ & $1.56 \pm 0.07$ & $2.85 \pm 0.07$ & $2.41 \pm 0.19$ & 7.2 & $23.1 \pm 0.90$ \\
\hline Significance & ns & ns & ** & $\star *$ & ** & $\star *$ \\
\hline \multicolumn{7}{|l|}{ Treatments } \\
\hline Ck & $3.3 \pm 0.14$ & $1.33 \pm 0.09$ & $3.05 \pm 0.15$ & $1.99 \pm 0.18$ & 6.40 & $21.8 \pm 0.69$ \\
\hline $\mathrm{Cd}$ & $3.5 \pm 0.12(+5 \%)$ & $1.61 \pm 0.08(+21.4 \%)$ & $3.21 \pm 0.15(+5.13 \%)$ & $1.76 \pm 0.25(-11.5 \%)$ & $5.11(-21 \%)$ & $20.0 \pm 1.16(-8.29 \%)$ \\
\hline Significance & * & $\star \star$ & ns & $\star \star$ & ** & ** \\
\hline \multicolumn{7}{|l|}{ Timings } \\
\hline 3DAT & $2.9 \pm 0.05$ & $1.13 \pm 0.13$ & $3.48 \pm 0.12$ & $1.02 \pm 0.12$ & 4.72 & $17.6 \pm 0.56$ \\
\hline 6DAT & $3.3 \pm 0.11(+14.4 \%)$ & $1.55 \pm 0.07(+37.2)$ & $3.34 \pm 0.19(-3.9 \%)$ & $2.12 \pm 0.20$ (107\%) & $5.49(+16 \%)$ & $21.2 \pm 0.89(+20.2 \%)$ \\
\hline 9DAT & $4.0 \pm 0.10(+21.2 \%)$ & $1.74 \pm 0.06(+12.3)$ & $2.56 \pm 0.10(-26.5 \%)$ & $2.4 \pm 0.25(141 \%)$ & 7.06 (49\%) & $23.9 \pm 1.24(+12.9 \%)$ \\
\hline Significance & ** & ** & $\star *$ & $\star \star$ & $\star \star$ & ** \\
\hline
\end{tabular}

DAT, days after treatment; ns, non-significant. *Significant at $P \leq 0.05 ;{ }^{* *}$ significant at $P \leq 0.01$.

Savidge et al., 2002) or replacing them with biosynthetic intermediates (Porfirova et al., 2002; Sattler et al., 2003) to uncover the underlying mechanism in plants. Accumulation of tocopherol can be observed in response to multiple abiotic stresses (Havaux et al., 2000; Munne-Bosch and Alegre, 2002a). In the present study, the concentration of total and $\alpha$-tocopherol improved under Cd stress compared to the control treatment, suggesting its role during oxidative stresses. The role of tocopherols in ameliorating Cd stress is attributed to the activity of $\alpha$-tocopherol. Alpha tocopherol content increased in both genotypes under stress. However, the magnitude of increase was considerably lower in Jiu-Er-13XI than in Zheyou-50, strengthening the idea that sensitive plants show net loss of tocopherol during oxidative stresses (Munne-Bosch, 2005). The

TABLE 6 | Sole effects of genotypes, treatments, and timings on leaf tocopherol content and composition in rapeseed.

\begin{tabular}{|c|c|c|c|}
\hline & $\begin{array}{c}\text { Alpha }\left(\mathrm{mg} \mathrm{g}^{-1}\right. \\
\text { FW) }\end{array}$ & $\begin{array}{c}\text { Gamma (mg g } \\
\text { FW) }\end{array}$ & $\begin{array}{c}\text { Total Toc ( } \mathrm{mg} \mathrm{g}^{-1} \\
\text { FW) }\end{array}$ \\
\hline \multicolumn{4}{|l|}{ Genotypes } \\
\hline Jiu-Er-13XI & $2.8 \pm 0.1 b$ & $0.08 \pm 0.006 b$ & $3.0 \pm 0.19 b$ \\
\hline Zheyou-50 & $4.3 \pm 0.2 \mathrm{a}$ & $0.09 \pm 0.006 a$ & $4.4 \pm 0.19 a$ \\
\hline Significance & $\star *$ & $\star *$ & $\star *$ \\
\hline \multicolumn{4}{|l|}{ Treatments } \\
\hline Ck & $3.2 \pm 0.1 b$ & $0.10 \pm 0.007 \mathrm{a}$ & $3.3 \pm 0.19 b$ \\
\hline $\mathrm{Cd}$ & $3.9 \pm 0.2 \mathrm{a}(+22 \%)$ & $\begin{array}{c}0.07 \pm 0.005 b \\
(-27 \%)\end{array}$ & $\begin{array}{c}4.1 \pm 0.26 \mathrm{a} \\
(+25 \%)\end{array}$ \\
\hline Significance & ** & $* \star$ & $\star *$ \\
\hline \multicolumn{4}{|l|}{ Timings } \\
\hline 3DAT & $2.9 \pm 0.1 c$ & $0.11 \pm 0.009 a$ & $3.0 \pm 0.18 c$ \\
\hline 6DAT & $3.6 \pm 0.2 b(+21 \%)$ & $\begin{array}{c}0.08 \pm 0.006 \mathrm{~b} \\
(-24 \%)\end{array}$ & $\begin{array}{c}3.7 \pm 0.25 b \\
(+19.6 \%)\end{array}$ \\
\hline 9DAT & $4.1 \pm 0.3 \mathrm{a}(+14 \%)$ & $\begin{array}{c}0.06 \pm 0.003 c \\
(-43 \%)\end{array}$ & $\begin{array}{c}4.4 \pm 0.34 \mathrm{a} \\
(+44.0 \%)\end{array}$ \\
\hline Significance & ** & $\star \star$ & $\star *$ \\
\hline
\end{tabular}

$D A T$, days after treatment; $n s$, non-significant. ${ }^{*}$ Significant at $P \leq 0.01$. increase in $\alpha$-tocopherol was accompanied by the decrease in $\gamma$-tocopherol, suggesting the upregulation of VTE4.

The role of $\alpha$-tocopherol is well known in protecting PUFA from oxidative damage (Sattler et al., 2004a). In the current experiment, the decrease in total fatty acid content of Jiu-Er13XI might be due to the low production of tocopherol, while in Zheyou-50, the increase in net fatty acid content was attributed to the protection provided by $\alpha$-tocopherol. Alpha tocopherol provided protection to PUFA in Zheyou-50 by quenching the

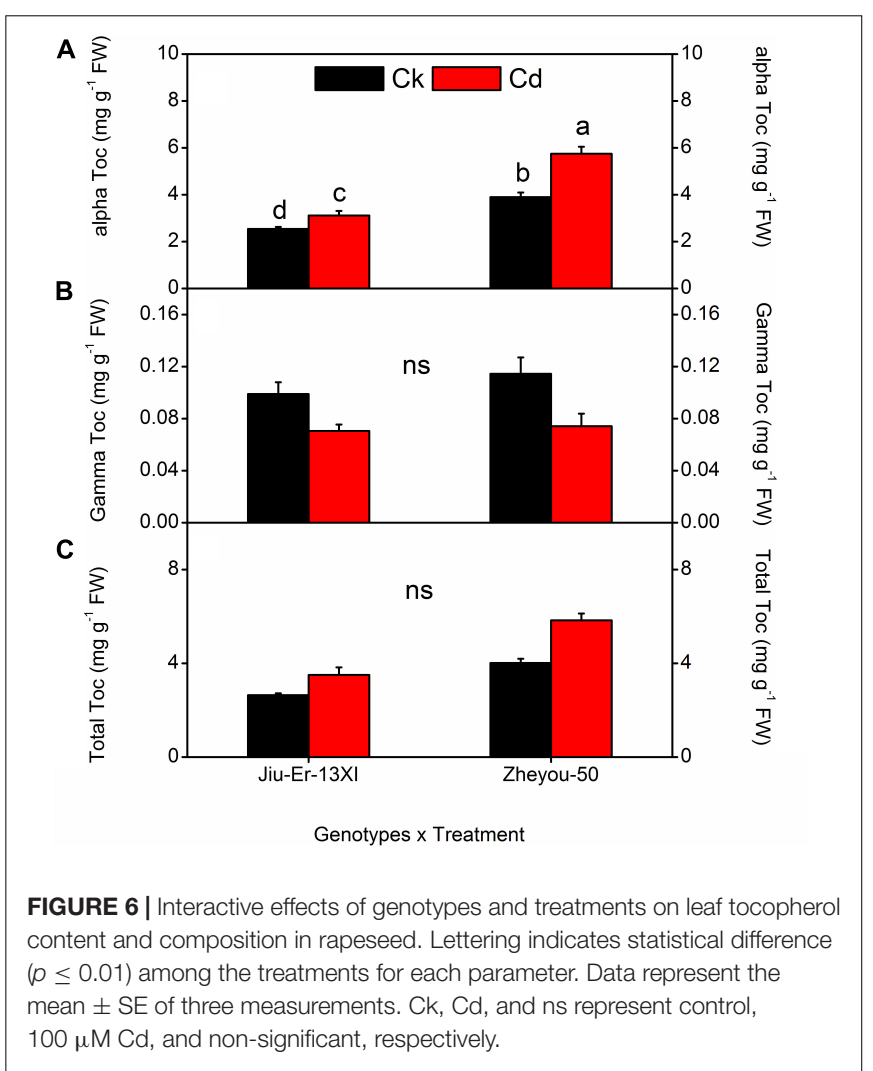



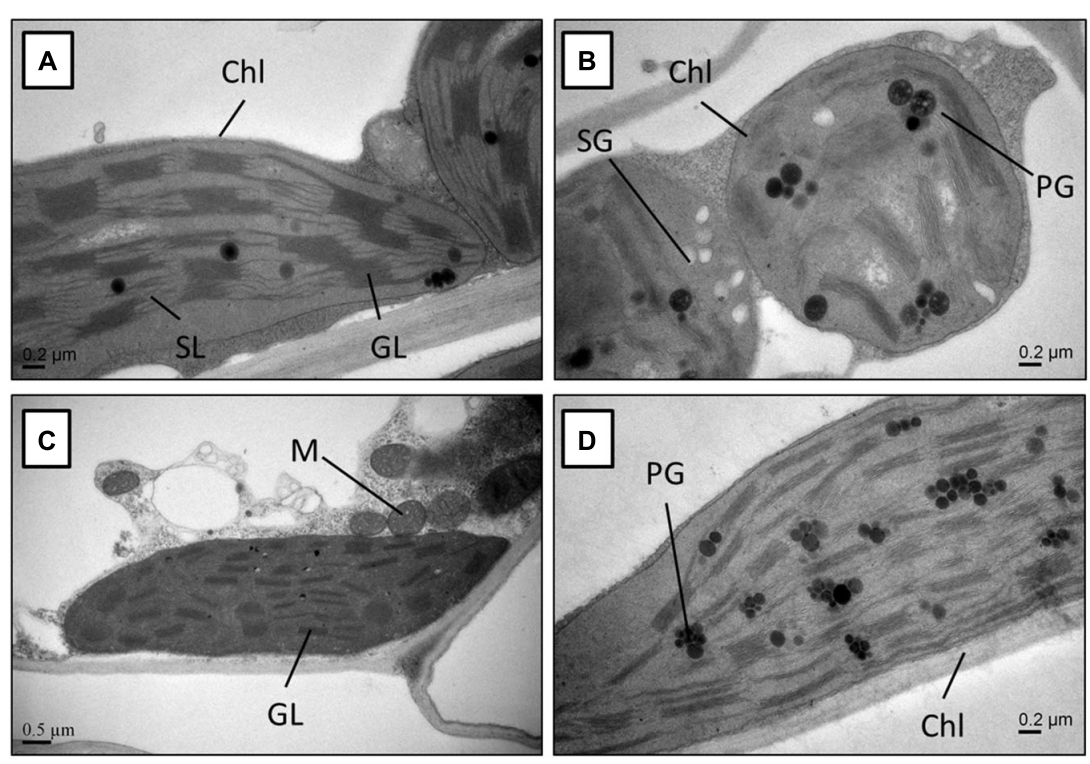

FIGURE 7 | Transmission electron micrograph of the leaf mesophyll cells from Jiu-Er-13XI ( $\mathrm{A}=\mathrm{Ck}, \mathrm{B}=100 \mu \mathrm{M} \mathrm{Cd})$, and Zheyou-50 (C = Ck, D = 100 $\mu$ M Cd). Labels: Ch, chloroplast; SG, starch grain; PG, plastoglobule; M, mitochondrion; GL, granallamella; SL, stromal lamella.

superoxide radicals, as ROS accumulation was reduced in this genotype compared to the Jiu-Er-13XI. MDA is the oxidative product of linolenic acid (Farmer 2007). In Jiu-Er-13XI, decrease in linolenic acid was accompanied by increase in MDA, showing the peroxidation of lipid membranes, while there was no such increase or decrease shown by Zheyou-50 for MDA and linolenic acid, respectively.

This view is further strengthened by the structure of chloroplast (Figure 7). In Jiu-Er-13XI, the chloroplast is completely deformed with destroyed thylakoid membranes and accumulation of starch granules, suggesting the oxidation of PUFA by ROS, and abnormality in sugar transport (Figure 7B). Abnormality in starch metabolism of Jiu-Er-13XI under Cd stress suggests the alternate function of tocopherol other than antioxidant (Maeda et al., 2006). The function of tocopherols in restricting the absorption of $\mathrm{Cd}$ and inhibiting its transport to upper parts of plant is not well documented. However, in the present study, reduction in absorption of Cd by roots and its limited translocation to aerial plant parts in Zheyou-50 might have been mediated by tocopherols.

\section{CONCLUSION}

The current study concludes that genotypic differences were observed in Cd tolerance of two oilseed rape varieties. Zheyou50 , with higher tocopherol content, exhibited better tolerance to Cd stress than Jiu-Er-13XI in terms of all studied parameters. The reduction in absorption and translocation of $\mathrm{Cd}$ and scavenging of reactive oxygen species by tolerant genotypes indicate the involvement of tocopherol in Cd stress amelioration. The current study suggests that the plants having high tocopherol content can withstand Cd stress effectively. The outcomes of the present investigation will serve as a source of valuable information for the scientific fraternity engaged in developing Cd-tolerant oilseed rape genotypes. However, further studies must be conducted in order to explore the underlying mechanism of tolerance to $\mathrm{Cd}$ stress in plants.

\section{DATA AVAILABILITY STATEMENT}

All datasets for this study are included in the article/Supplementary Material.

\section{AUTHOR CONTRIBUTIONS}

EA conceived and oversaw the work. EA, JMS, and SAHB executed the trial. $\mathrm{ZH}, \mathrm{MI}$, and $\mathrm{SH}$ made the figures and tables. HR, ANS, and MA analyzed the data. EA, MA-D, and SAHB wrote the manuscript. SAk and SAi revised the manuscript. All authors have carefully read and approved the article.

\section{FUNDING}

The study was funded by Researchers Supporting Project number (RSP 2020/26), King Saud University, Riyadh, Saudi Arabia, Key Project of Research and Development Plan of Zhejiang (2018C02SA780973), and Natural Science Foundation of China (31401506).

\section{SUPPLEMENTARY MATERIAL}

The Supplementary Material for this article can be found online at: https://www.frontiersin.org/articles/10.3389/fpls.2020. 547133/full\#supplementary-material 


\section{REFERENCES}

Abbasi, A., Hajirezaei, M., Hofius, D., Sonnewald, U., and Voll, L. M. (2007). Specific roles of $\alpha$ - and $\gamma$-tocopherol in abiotic stress responses of transgenic tobacco (Nicotiana tabacum L.). Plant Physiol. 143, 1720-1738. doi: 10.1104/ pp.106.094771

Ahmad, P., Nabi, G., and Ashraf, M. (2011). Cadmium-induced oxidative damage in mustard (Brassica juncea L.) Czern \& Coss) plants can be alleviated by salicylic acid. South Afr. J. Bot. 77, 36-44. doi: 10.1016/j.sajb.2010.05.003

Ali, E., Hussain, N., Shamsi, I. H., Jabeen, Z., Siddiqui, M. H., and Jiang, L. (2018). Role of jasmonic acid in improving tolerance of rapeseed (Brassica napus L.) to Cd toxicity. J. Zhejiang Univ. Sci. B 19, 130-146. doi: 10.1631/jzus.b1700191

Ali, E., Maodzeka, A., Hussain, N., Shamsi, I. H., and Jiang, L. (2015). The alleviation of cadmium toxicity in oilseed rape (Brassica napus) by the application of salicylic acid. Plant Growth Regul. 75, 641-655. doi: 10.1007/ s10725-014-9966-0

Borges, R., Miguel, E. C., Dias, J. M. R., Da, C. M., Ricardo, E. B. S., Oliveira, J. G., et al. (2004). Ultrastructural, physiological and biochemical analyses of chlorate toxicity on rice seedlings. Plant Sci. 166, 1057-1062. doi: 10.1016/j. plantsci.2003.12.023

Bukhari, S. A. H., Zheng, W., Xie, L., Zhang, G., Shang, S., and Wu, F. (2016). Crinduced changes in leaf protein profile, ultrastructure and photosynthetic traits in the two contrasting tobacco genotypes. Plant Growth Regul. 79, 147-156. doi: 10.1007/s10725-015-0120-4

Chen, M. X., Wang, Z., Zhu, Y., Li, Z. L., Hussain, N., Zhang, G. P., et al. (2012). Effect of TRANSPARENT TESTA 2 on seed fatty acid biosynthesis and tolerance to environmental stresses during young seedling establishment in Arabidopsis. Plant Physiol. 160, 1023-1036. doi: 10.1104/pp.112.202945

Collakova, E., and DellaPenna, D. (2001). Isolation and functional analysis of homogentisate phytyltransferase from Synechocystis sp. PCC 6803 and Arabidopsis. Plant Physiol. 127, 1113-1124. doi: 10.1104/pp.010421

Collakova, E., and DellaPenna, D. (2003). The role of homogentisate phytyltransferase and other tocopherol pathway enzymes in the regulation of tocopherol synthesis during abiotic stress. Plant Physiol. 133, 930-940. doi: 10.1104/pp.103.026138

Collin, V. C., Eymery, F., Genty, B., Rey, P., and Havaux, M. (2008). Vitamin E is essential for the tolerance of Arabidopsis thaliana to metal-induced oxidative stress. Plant Cell Environ. 31, 244-257.

Di Toppi, L. S., and Gabbrielli, R. (1999). Response to cadmium in higher plants. Environ. Exp. Bot. 41, 105-130. doi: 10.1016/s0098-8472(98)00058-6

Dorta, D. J., Leite, S., and DeMarco, K. C. (2003). A proposed sequence of events for cadmium-induced mitochondrial impairment. J. Inorg. Biochem. 97, 251-257. doi: 10.1016/s0162-0134(03)00314-3

Du, X., Hussain, N., Li, Z., Chen, X., Hua, S., Zhang, D., et al. (2015). Effect of Gibberellin on the biosynthesis of tocopherols in oilseed rape (Brassica napus L.) and Arabidopsis. J. Agric. Food Chem. 63, 360-369. doi: 10.1021/jf505312c

Feng, R. W., Wei, C. Y., Tu, S. X., Ding, Y. Z., and Song, Z. G. (2013). A dual role of Se on Cd toxicity: evidences from the uptake of Cd andsome essential elements and the growth responses in paddyrice. Biol. Trace Elem. Res. 151, 113-121. doi: 10.1007/s12011-012-9532-4

Frankel, E. N. (2005). Lipid Oxidation. Philadelphia, PA:Woodhead Publishing Ltd.

Fukuzawa, K., Tokumura, A., Ouchi, S., and Tsukatani, H. (1982). Antioxidant activities of tocopherols on $\mathrm{Fe} 2$-ascorbate-induced lipid peroxidation in lecithin liposomes. Lipids 17, 511-513. doi: 10.1007/bf02535334

Garcia-Plazaola, J. I., and Becerril, J. M. (2000). Effects of drought on photoprotective mechanisms in European beech (Fagus sylvatica L.) seedlings from different provenances. Trees Strut. Funct. 14, 485-490. doi: 10.1007/ s004680000068

Gong, H. J., Chen, K. M., Zhao, Z. G., Chen, G. C., and Zhou, W. J. (2008). Effects of silicon on defense of wheat against oxidative stress under drought at different developmental stages. Biol. Plant. 52, 592-596. doi: 10.1007/s10535-008-0118-0

Gramegna, G., Rosado, D., Sánchez Carranza, A. P., Cruz, A. B., Simon-Moya, M., Llorente, B., et al. (2019). PHYTOCHROME-INTERACTING FACTOR 3 mediates light-dependent induction of tocopherol biosynthesis during tomato fruit ripening. Plant Cell Environ. 42, 1328-1339. doi: 10.1111/pce. 13467

Gratão, P. L., Monteiro, C. C., Rossi, M. L., Martinelli, A. P., Peres, L. E. P., Medici, L. O., et al. (2009). Differential ultra structural changes in tomato hormonal mutants exposed to cadmium. Environ. Exp. Bot. 67, 387-394. doi: 10.1016/j. envexpbot.2009.06.017

Grusak, M. A. (1999). Genomics-assisted plant improvement to benefit human nutrition and health. Trends Plant Sci. 4, 164-166. doi: 10.1016/s1360-1385(99) 01400-4

Grusak, M. A., DellaPenna, D., and Welch, R. M. (1999). Physiologic processes affecting the content and distribution of phytonutrients in plants. Nutr. Rev. 57, S27-S33.

Havaux, M., Bonfils, J. P., Lütz, C., and Niyogi, K. K. (2000). Photodamage of the photosynthetic apparatus and its dependence on the leaf developmental stage in the npq1 Arabidopsis mutant deficient in the xanthophyll cycle enzyme violaxanthin de-epoxidase. Plant Physiol. 124, 273-284. doi: 10.1104/pp.124. 1.273

Havaux, M., Eymery, F., Porfirova, S., Rey, P., and Dormann, P. (2005). Tocochromanol protects against photo inhibition and oxidative stress in Arabidopsis thaliana. Plant Cell 17, 3451-3469. doi: 10.1105/tpc.105. 037036

Hawkes, J. S. (1997). Heavy metals. J. Chem. Edu. 74, 1369-1374.

Hodges, D. M., DeLong, J. M., Forney, C. F., and Prange, R. K. (1999). Improving the thiobarbituric acid-reactive-substances assay for estimating lipid peroxidation in plant tissues containing anthocyanin and other interfering compounds. Planta 207, 604-611. doi:10.1007/s00425005 0524

Hüsken, A., Baumert, A., Strack, D., Becker, H. C., Möllers, C., and Milkowski, C. (2005). Reduction of sinapate ester content in transgenic oilseed rape (Brassica napus) by dsRNAi-based suppression of BnSGT1 gene expression. Mol. Breeding 16, 127-138. doi: 10.1007/s11032-005-6825-8

Jia, Y., Tang, S. R., Ju, X. H., Shu, L. N., Tu, S. X., Feng, R. W., et al. (2011). Effects of elevated $\mathrm{CO}_{2}$ levels on root morphological traitsand $\mathrm{Cd}$ uptakes of two Lolium species under Cd stress. J. Zhejiang Univ. Sci. B 12, 313-325. doi: 10.1631/jzus.b1000181

Jiang, M., and Zhang, J. (2001). Effect of abscisic acid on active oxygen species, antioxidative defence system and oxidative damage in leaves of maize seedlings. Plant Cell Physiol. 42, 1265-1273. doi: 10.1093/pcp/pce162

Kim, S. E., Lee, C. J., Ji, C. Y., Kim, H. S., Park, S. U., Lim, Y. H., et al. (2019). Transgenic sweetpotato plants overexpressing tocopherol cyclase display enhanced $\alpha$-tocopherol content and abiotic stress tolerance. Plant Physiol. Biochem. 144, 436-444. doi: 10.1016/j.plaphy.2019.09.046

Krieger-Liszkay, A. (2005). A singlet oxygen production in photosynthesis. J. Exp. Bot. 56, 337-346. doi: 10.1093/jxb/erh237

Li, F., Wu, Q. Y., Sun, Y. L., Wang, L. Y., Yang, X. H., and Meng, Q. W. (2010) Overexpression of chloroplastic monodehydroascorbate reductase enhanced tolerance to temperature and methyl viologen-mediated oxidative stresses. Physiol. Plant. 139, 421-434.

Li, Y. L., Hussain, N., Zhang, L. M., Chen, X. Y., Ali, E., and Jiang, L. X. (2013). Correlations between tocopherol and fatty acid components in germplasm collections of Brassica oilseeds. J. Agri. Food Chem. 61, 34-40. doi: 10.1021/ jf3042837

Lima, A. I. G., Pereira, S. I. A., de Almeida Paula Figueira, E. M., Caldeira, G. C. N., and de Matos Caldeira, H. D. Q. (2006). Cadmium detoxification in roots of Pisum sativum seedlings: relationship between toxicity levels, thiol pool alterations and growth. Environ. Exp. Bot. 55, 149-162. doi: 10.1016/j. envexpbot.2004.10.008

Liu, D., Jiang, W., Wang, W., and Zhai, L. (1995). Evaluation of metal ion toxicity on root tip cells by the Allium test. Isr. J. Plant Sci. 43, 125-133. doi: 10.1080/ 07929978.1995.10676598

Livak, K. J., and Schmittgen, T. D. (2001). Analysis of relative gene expression data using real-time quantitative PCR and the $2^{-} \Delta \Delta \mathrm{C}$ method. Methods 25 , 402-408. doi: 10.1006/meth.2001.1262

López-Millán, A. F., Sagardoy, R., Solanas, M., and Abadía, A. (2009). Cadmium toxicity in tomato (Lycopersicon esculentum) plants grown in hydroponics. Environ. Exp. Bot. 65:376. doi: 10.1016/j.envexpbot.2008.11.010

Maeda, H., Sakuragi, Y., Bryant, D. A., and DellaPenna, D. (2005). Tocopherols protect Synechocystis sp. strain PCC 6803 from lipid peroxidation. Plant Physiol. 138, 1422-1435. doi: 10.1104/pp.105.061135

Maeda, H., Song, W., Sage, T. L., and DellaPenna, D. (2006). Tocopherols play a crucial role in low temperature adaptation and phloem loading in Arabidopsis. Plant Cell 18, 2710-2732. doi: 10.1105/tpc.105.039404 
Mène-Saffrané, L., and DellaPenna, D. (2010). Biosynthesis, regulation and functions of tocochromanols in plants. Plant Physiol. Biochem. 48, 301-309. doi: 10.1016/j.plaphy.2009.11.004

Munne-Bosch, S. (2005). The role of $\alpha$-tocopherol in plant stress tolerance. J. Plant Physiol. 162, 743-748. doi: 10.1016/j.jplph.2005.04.022

Munne-Bosch, S., and Alegre, L. (2001). Subcellular compartmentation of the diterpene carnosic acid and its derivatives in the leaves of rosemary. J. Plant Physiol. 125, 1094-1102. doi: 10.1104/pp.125.2.1094

Munne-Bosch, S., and Alegre, L. (2002a). Interplay between ascorbic acid and lipophilic antioxidant defences in chloroplasts of water-stressed Arabidopsis plants. FEBS Lett. 524, 145-148. doi: 10.1016/s0014-5793(02)03041-7

Munne-Bosch, S., and Alegre, L. (2002b). The function of tocopherols and tocotrienols in plants. Crit. Rev. Plant Sci. 21, 31-57. doi: 10.1201/ 9781420080391-8

Nowicka, B., Fesenko, T., Walczak, J., and Kruk, J. (2020). The inhibitor-evoked shortage of tocopherol and plastoquinol is compensated by other antioxidant mechanisms in Chlamydomonas reinhardtii exposed to toxic concentrations of cadmium and chromium ions. Ecotoxicol. Environ. Saf. 191:110241. doi: 10.1016/j.ecoenv.2020.110241

Pathak, N., and Khandelwal, S. (2006). Oxidative stress and apoptotic changes in murine splenocytes exposed to cadmium. Toxicology 220, 26-36. doi: 10.1016/ j.tox.2005.11.027

Porfirova, S., Bergmuller, E., Tropf, S., Lemke, R., and Dormann, P. (2002). Isolation of an Arabidopsis mutant lacking vitamin $\mathrm{E}$ and identification of a cyclase essential for all tocopherol biosynthesis. Proc. Natl. Acad. Sci. U.S.A. 99, 12495-12500. doi: 10.1073/pnas.182330899

Sattler, S. E., Cahoon, E. B., Coughlan, S. J., and DellaPenna, D. (2003). Characterization of tocopherol cyclases from higher plants and cyanobacteria. Evolutionary implications for tocopherol synthesis and function. Plant Physiol. 132, 2184-2195. doi: 10.1104/pp.103.024257

Sattler, S. E., Cheng, Z., and DellaPenna, D. (2004a). From Arabidopsis to agriculture: engineering improved vitamin E content in soybean. Trends Plant Sci. 9, 365-367. doi: 10.1016/j.tplants.2004.06.002

Sattler, S. E., Gilliland, L. U., Magallanes-Lundback, M., Pollard, M., and DellaPenna, D. (2004b). Vitamin E is essential for seed longevity and for preventing lipid peroxidation during germination. Plant Cell 16, 1419-1432. doi: 10.1105/tpc.021360

Savidge, B., Weiss, J. D., Wong, Y. H., Lassner, M. W., Mitsky, T. A., Shewmaker, C. K., et al. (2002). Isolation and characterization of homogentisate phytyltransferase genes from Synechocystis sp.PCC 6803 and Arabidopsis. Plant Physiol. 129, 321-332. doi: 10.1104/pp.010747

Schledz, M., Seidler, A., Beyer, P., and Neuhaus, G. (2001). A novel phytyltransferase from Synechocystis sp.PCC 6803 involved in tocopherol biosynthesis. FEBS Lett. 499, 15-20. doi: 10.1016/s0014-5793(01)02508-x
Scholz, R. W., Graham, K. S., and Wynn, M. K. (1990). "Interaction of glutathione and a-tocopherol in the inhibition of lipid peroxidation of rat liver microsomes," in Biological Oxidation Systems, eds C. C. Eddy, G. A. Hamilton, and K. M. Madyastha (San Diego, CA: Academic Press), 841-867. doi: 10.1016/b978-012-584552-6.50027-6

Steel, R. G. D., and Torrie, J. H. (1980). Principles and Procedures of Statistics: a Biometrical Approach, 2nd Edn. New York, NY: McGraw-Hill.

Tang, Y., Fu, X., Shen, Q., and Tang, K. (2016). Roles of MPBQ-MT in promoting $\alpha / \gamma$-tocopherol production and photosynthesis under high light in lettuce. PLoS One 11:e0148490. doi: 10.1371/journal.pone.0148490

Uzunova, A. N., and Popova, L. P. (2000). Effect of salicylic acid on the leaf anatomy and chloroplast ultrastructure of barley plants. Photosynthetica 38, 243-250. doi: 10.1023/a:1007226116925

Vijaranakul, U., Jayaswal, R. K., and Nadakavukaren, M. J. (2001). Alteration in chloroplast ultrastructure of suspension cultured Nicotiana tabacum cells by cadmium. Sci. Asia 27, 227-231.

Wang, F., Chen, F., Cai, Y., Zhang, G., and Wu, F. (2011). Modulation of exogenous glutathione in ultrastructure and photosynthetic performance against Cd stress in the two barley genotypes differing in Cd tolerance. Biol. Trace Elem. Res. 144, 1275-1288. doi: 10.1007/s12011-011-9121-y

Wang, L. S., Wang, L., Wang, L., Wang, G., Li, Z. H., and Wang, J. J. (2009). Effect of 1-butyl-3-methylimidazolium tetrafluoroborate on the wheat (Triticuma estivum L.) seedlings. Environ. Toxicol. 24, 296-303. doi: 10.1002/tox.20435

Wu, F. B., Dong, J., Qian, Q. Q., and Zhang, G. P. (2005). Subcellular distribution and chemical form of $\mathrm{Cd}$ and $\mathrm{Cd}-\mathrm{Zn}$ interaction in different barley genotypes. Chemosphere 60, 1437-1446. doi: 10.1016/j.chemosphere.2005.01.071

Zhou, Y. J., Zhang, S. P., and Liu, C. W. (2009). The protection of selenium on ROS-mediated apoptosis by mitochondria dysfunction in cadmium-induced LLC-PK1 cells. Toxicol. In Vitro 23, 288-294. doi: 10.1016/j.tiv.2008.12.009

Conflict of Interest: The authors declare that the research was conducted in the absence of any commercial or financial relationships that could be construed as a potential conflict of interest.

The handling editor declared a shared affiliation with one of the authors EA at the time of review.

Copyright (C) 2020 Ali, Hassan, Irfan, Hussain, Rehman, Shah, Shahzad, Ali, Alkahtani, Abdel-Daim, Bukhari and Ali. This is an open-access article distributed under the terms of the Creative Commons Attribution License (CC BY). The use, distribution or reproduction in other forums is permitted, provided the original author(s) and the copyright owner(s) are credited and that the original publication in this journal is cited, in accordance with accepted academic practice. No use, distribution or reproduction is permitted which does not comply with these terms. 